\title{
Determinants of pastoralists' participation in commercial fodder markets for livelihood resilience in drylands of northern Kenya: Case of Isiolo
}

\author{
Saada Mohamed Sala ${ }^{1 *}$, David Jakinda Otieno ${ }^{1}$, Jonathan Nzuma ${ }^{1}$ and Stephen Mwangi Mureithi²
}

\begin{abstract}
Feed insecurity associated with prolonged and recurrent droughts remains a perennial challenge impeding livestock production and a major source of resource-based conflicts in the drylands of many developing countries such as Kenya. Thus, the emerging fodder markets in the drylands act as a secondary source of livestock feed to augment the natural pastures and hence play a crucial role in meeting the year-round feed requirements of pastoralists. However, little information exists on the factors influencing pastoralists to purchase fodder for their own livestock amid their long-held cultural beliefs in using natural pastures for forage. Using primary household survey data from a multi-stage sample of 201 pastoralists, this study assessed socio-economic and institutional factors that influence the pastoralists' participation in fodder markets in Isiolo County, Kenya. Both descriptive statistics and a Heckman two-step model were applied in data analysis. The findings showed that pastoralists' decisions to purchase fodder are significantly influenced by access to credit, weather and market information, land tenure system, exposure to shocks, off-farm income, age, gender and proximity to towns. The amount of fodder purchased was significantly affected by access to weather information, exposure to shocks and livestock holdings. These results underscore the importance of improving pastoralists' access to prerequisite institutional support services to enhance their access to fodder and livestock markets, basic services and increased integration into the broader market economy.
\end{abstract}

Keywords: Fodder, Market participation, Pastoralists, Isiolo, Kenya

\section{Introduction}

Livestock production in the arid and semi-arid lands (ASALs) of Kenya is predominately through pastoralism which is characterized by extensive grazing systems, seasonal livestock mobility and communal management of natural resources (Republic of Kenya 2012). The natural rangelands constitute the bulk of livestock feed resources in the drylands and are unevenly distributed in space and time; hence, mobility is crucial for effective and efficient utilization of these resources (Wanyoike et al. 2018;

\footnotetext{
*Correspondence: sdmohamed728@gmail.com

'Department of Agricultural Economics, University of Nairobi, P.O. Box 29053-00625, Nairobi, Kenya

Full list of author information is available at the end of the article
}

Wasonga et al. 2016). However, the biomass productivity and carrying capacity of these rangelands are threatened by several factors, including land degradation, overgrazing due to expanding livestock population, encroachment by invasive plant species, uncontrolled land use changes and adverse effects of climate change (Ayele et al. 2012; IGAD 2017). Therefore, sustainable development of the livestock sector has been hampered by the perennial challenge of feed deficits, which is estimated at $70 \%$ of the total annual fodder requirements of about 5.5 billion bales (a bale is equivalent to 20kg) (KIPPRA 2018). This has resulted in a significant loss of livestock due to starvation during frequent long dry spells (Koech et al. 2016; Mureithi 2018). 
Over time, concerted efforts and investments have been undertaken by the pastoral communities themselves, the Government of Kenya and development partners to promote adaptation measures aimed at meeting the feed requirements for Kenya's livestock. For instance, the Borana pastoralists in Isiolo County have revived their traditional customary institutions, which were used to govern and define the use of natural grazing resources such as pasture and water. This involves distinctly partitioning the grazing resources into three units called dedha which include wet and dry season grazing areas and drought grazing reserves. These units are managed by the elected council of elders who are also known as dedha. This system allows pastoralists to periodically move livestock according to the different seasons and ensures that the drought reserves are not depleted and allow the dry season grazing to rejuvenate (Republic of Kenya 2015; Cormack 2016). These traditional institutions are noted to be crucial components of pastoralism and sustainable rangeland management (Wasonga et al. 2016).

Moreover, various fodder production technologies, including range pasture establishment, natural pasture improvement and pasture seed production in the drylands, have been promoted in Kenya to augment the communal grazing resources. Consequently, pastoral communities are gradually adopting fodder production as an alternative source of livestock feeds (Mwaura et al. 2015; Nyangaga et al. 2009). Enclosure systems have also been adopted for fodder production and rehabilitation of degraded land in some ASAL areas such as Baringo and West Pokot Counties of Kenya. These enclosures are used to preserve pasture and hence provide strategic grazing reserves during the dry season especially for the lactating stock, young stock or fattening bulls (Nyberg et al. 2015; Wairore et al. 2015).

Specifically in Isiolo County, fodder production and rangeland rehabilitation through pasture reseeding technology has been strongly promoted by development partners in collaboration with the government (Mureithi 2018). These include the World Food Programme's (WFP) food for asset (FFA) creation project which began 2009 in thirteen dryland Counties. The project was implemented through the National Drought Management Authority (NDMA) with the main objective of boosting the adaptive capacity of pastoralists to withstand shocks, become independent of relief food and attain sustainable diversified livelihoods (WFP 2013; 2016; Thomas et al. 2016). The project's concept was anchored on resilience-building through asset creation, considered to be more cost-effective and better in stabilizing livelihoods than humanitarian emergency responses (AU-IBAR 2012; Pain and Levine 2012; Muricho et al. 2019). The implementing partners included the Resilience and Economic Growth in the Arid Lands-Accelerated Growth (REGAL-AG), Action Aid Kenya (AAK), Accelerated Value Chain Development-Livestock Component (AVCD-LC), NDMA and Isiolo County government.
The asset creation component of the FFA project entailed empowering pastoralists, through a group-based approach, to adopt rainwater harvesting innovations for producing drought-tolerant livestock feeds. Collective action has been widely recognized as an effective means of fostering rural development and improving risk management strategies and hence is a vital coping strategy for building the resilience of rural communities (Coppock et al. 2006; Ngigi et al. 2015). The REGAL-AG supported pastoralists to set up fodder groups and demonstration plots which were used for technical trainings on land tilling, seeding, processing hay and storage. Additionally, the REGAL-AG constructed a hay barn storage facility and procured harvesting and baling equipment under its business development grant component (USAID 2015). On the other hand, the AVCDLC project provided fodder producer groups with rangeland grass seeds, and promoted rain-water harvesting structures and market linkages for fodder selling (Kutu and Wamwere-Njoroge 2017). Following these forms of support, there are currently about 22 fodder producer groups in Isiolo County producing and selling fodder to their members and non-members (Mureithi 2018). The current study focused on the pastoral households who are members of these fodder groups in order to analyse their decision-making behaviour in relation to buying fodder for their own livestock.

These developments have led to the emergence of livestock feed markets in Kenya's ASAL regions although the degree of commercial orientation varies across different dryland Counties. In most pastoral areas like Isiolo, there has been a common practice of "cut and carry" where pastoralists collect from the natural pastures not only for their own use but also to sell in the market for income (Wanyoike et al. 2018). In the enclosures, contractual grazing arrangements are used to sell the standing hay at a fee for a given period of time, especially during the dry seasons; this is commonly practiced in Baringo, West Pokot, Kajiado and Makueni Counties. The enclosures have been cited as providing the pastoralists with opportunities to generate income, through the sale of hay, grass seeds and pasture leasing (Lugusa 2015; Mureithi et al. 2015; Wairore et al. 2015; Omollo et al. 2018).

There is also growing demand for cultivated fodder which is harvested, baled and sold in the open-air markets. For instance, the fodder marketing structure in Mandera County is informal with no clear governance of power relations and lacks a well-coordinated supply chain system (Nyangaga et al. 2009). In Baringo County, the grass seed market is formalized, as transactions are based on contractual arrangements that integrate input provision and purchase of seeds. This is due to the involvement of large private sector players such as the 
Kerio Valley Development Authority (KVDA), Rehabilitation of Arid Environments Trust (RAE) and Kenya Agricultural and Livestock Research Organization (KALRO) (Lugusa et al. 2016). Omollo et al. (2017) noted that grass seed markets in Kajiado and Makueni Counties are still developing and informal in nature with limited private sector participation.

In Isiolo County, most of the individual fodder producers who cultivate grass often sell it as standing pasture for grazing, mainly to livestock traders delivering livestock to Isiolo markets. However, the fodder market in Isiolo is still at the infancy stage and is mainly concentrated around the town centre, due to the growing dairy cattle and goat farming (Wanyoike et al. 2018). Besides the limited fodder produced within the county mostly by groups and few individuals, the Isiolo fodder market also gets fodder supplies from neighbouring counties of Meru, Laikipia and Nanyuki where grass and wheat farming is common (Republic of Kenya 2013). Despite these trends, pastoralists' willingness to purchase hay/fodder for their own livestock is still relatively low, because of their long-held cultural beliefs in using naturally occurring grass for livestock feeds (IGAD 2017). Further, Wanyoike et al. (2018) noted that the use of purchased feeds is low among the pastoralists in Isiolo County as the majority still rely on communal grazing resources. Therefore, it is of considerable empirical interest to analyse the potential factors influencing pastoralists' decisions to purchase fodder for their livestock as well as challenges associated with fodder markets. This is because access to livestock feed either through hay production or through hay purchase has significantly contributed to the income levels of the pastoralists and agro-pastoralists in northern Ethiopia (Berhe et al. 2016).

Most of the previous studies have principally focused on the fodder production dynamics in the drylands of Kenya. For instance, Koech (2014) and Koech et al. (2016) explored the potential biomass yield and the effect of storage duration on the quality of six common grass species in Kenya, respectively. Omollo et al. (2018) assessed the determinants of pastoral and agro-pastoral households' participation in fodder production in the southern drylands of Kenya and found that education, access to extension services, membership to social/development group and gender of household head were the key determinants. Likewise, other studies have focused mainly on the grass seed value chain in terms of the existing markets, diverse actors, challenges and opportunities that exist along the chain in Baringo, Kajiado and Makueni Counties, respectively (Lugusa et al. 2016; Omollo et al. 2017). The current study contributes to the literature by addressing two key objectives; firstly, assessing the effects of socio-economic and institutional factors on pastoralists' decisions to purchase fodder and secondly, evaluating the determinants of the amount of fodder purchased. Analysis of these factors is vital for designing carefully targeted policy interventions that are compatible with the dynamic nature of pastoralists' lifestyles and livelihoods. This will aid in promoting commercially-oriented fodder production and ensuring efficient and enhanced market access for producer groups, thus enabling resilient livelihoods.

\section{Study area}

This study was conducted in Isiolo (Fig. 1), a typical ASAL county in northern Kenya, purposively selected because of the presence of emerging fodder groups' enterprises supported by the FFA project. The County covers a total land area of $25,350.6 \mathrm{~km}^{2}$ with three agroclimatic zones: the semi-arid, arid and very arid occupying the majority of the land area (KNBS 2019).

Traditionally, the county had a bimodal rainfall pattern with short rains in October and November, while long rains were occurring in March and May. However, this pattern has been interrupted by climate change; hence, rainfall is unpredictable and erratic in distribution. The average rainfall and temperatures are $580.2 \mathrm{~mm}$ and $29^{\circ} \mathrm{C}$, respectively (Republic of Kenya 2013).

Isiolo is among the largest livestock producing and marketing hubs in northern Kenya, with an estimated livestock population of 198,424 cattle, 398,903 goats, 361,836 sheep and 39,084 camels (KNBS 2009). Thus, the livestock sector accounts for over $80 \%$ of residents' livelihoods and $70 \%$ of the rural labour force and hence is the mainstay of the County's economy (Republic of Kenya 2013; Iruata et al. 2015). The county is often faced with severe vegetation deficit resulting from environmental degradation due to high incidences of overstocking, overgrazing and recurrent drought patterns (Republic of Kenya 2013; NDMA 2018).

The vegetation condition index ( $\mathrm{VCI})$ is one of the indicators monitored to measure the impact of drought on vegetation, by observing changes in vegetation and comparing them with historical values, and can provide information on the onset, duration and severity of drought. As shown in Fig. 2, recent reports from the National Drought Management Authority (NDMA) showed that Isiolo County has experienced severe vegetation deficits since 2009 (NDMA 2018). This was associated with a series of major droughts experienced in Kenya in 2000, 2005/2006, 2010/2011 and 2016/2017 causing massive livestock deaths and severe food shortages which affected 3.75 million and 2.7 million people, respectively, especially in the ASALs (KIPPRA 2018). For instance, the 2017 dry spell resulted in deterioration of the animals' body conditions, low birth rates and high mortality rates of over 10\% due to starvation (UN 2017).

The severe vegetation deficit is attributed to the poor regeneration of natural vegetation following the poor 


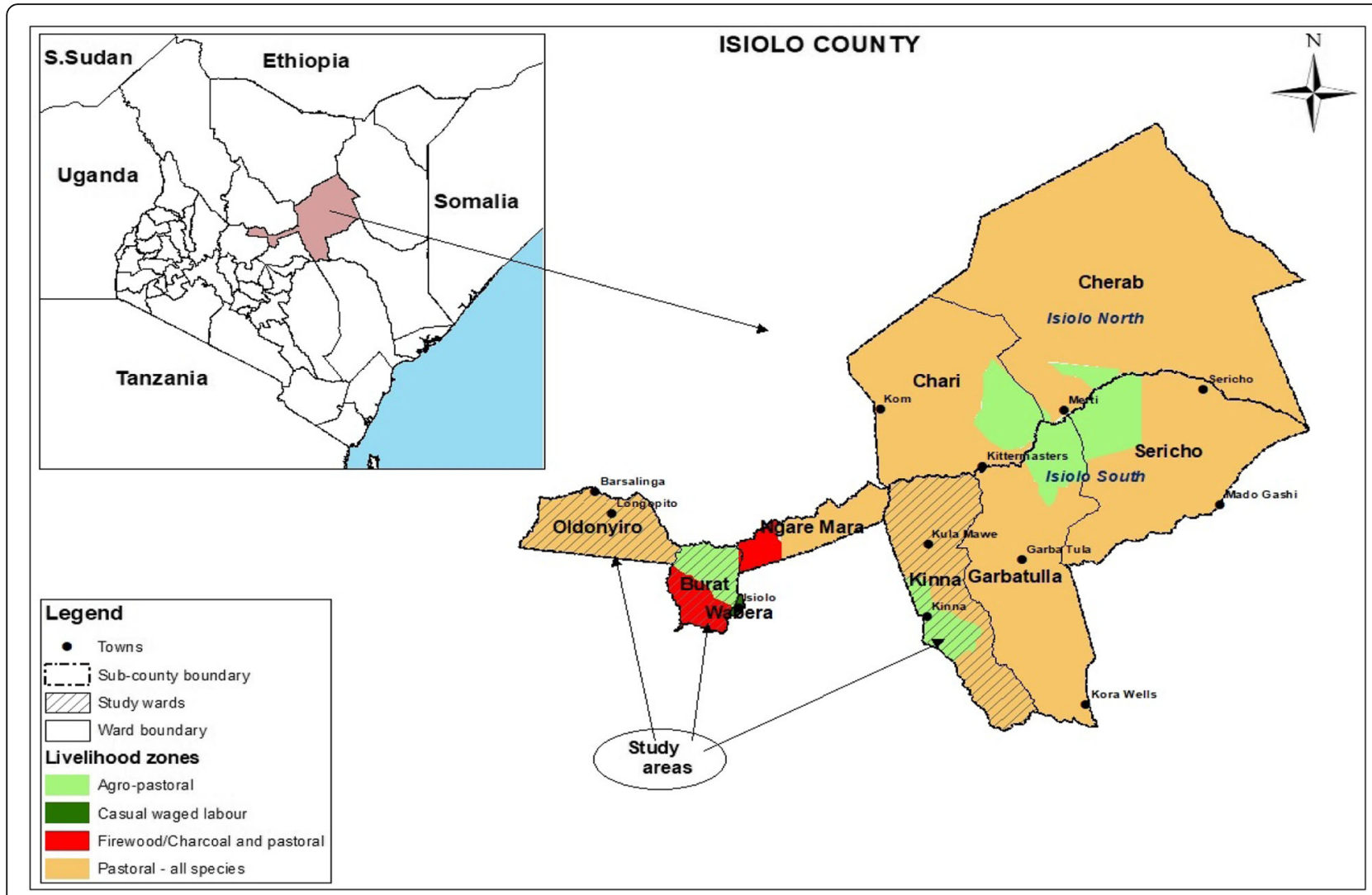

Fig. 1 Livelihood zones of Isiolo County and study sites. Source: Fews.netBoundaries:gadm.org (2019)

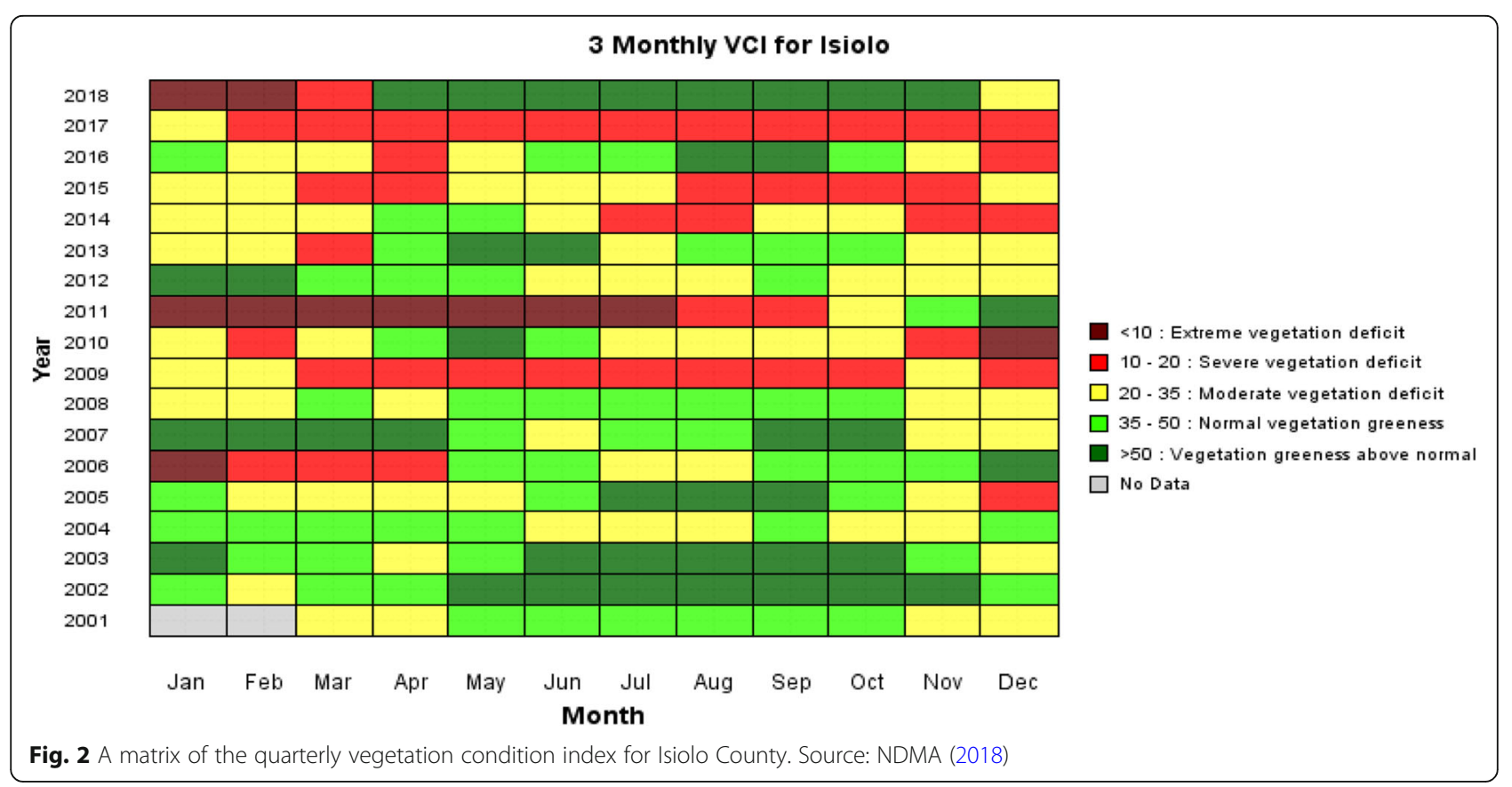


rainfall performance over the years. Figure 3 shows the amount of rainfall received and spatial distribution in Isiolo County between 2016 and 2018 as compared with the long-term average (NDMA 2018). This illustrates the seasonal and inter-annual variability of rainfall as the major factor that influences the availability and nutritional quality of pastures, thus accelerating resource-based conflicts between the herders in Isiolo and neighbouring ASAL counties (Republic of Kenya 2015). The grazing resources are abundant and rich in nutrients during the wet season, and poor in nutrients in the dry season (Republic of Kenya 2015). However, the wet season grazing resources are only accessed twice a year (Wasonga et al. 2016).

The constrained access to grazing resources and consequent deterioration of livestock presents a serious threat to livelihoods of approximately 268,002 people (KNBS 2019), two thirds of whom are already extremely poor as compared to the national average poverty level of $45 \%$ (KNBS 2009).

\section{Methods}

\section{Sampling design and data collection}

A multi-stage sampling procedure comprising three stages was used to select the respondents for this study. In the first stage, Isiolo County was purposively selected because of the presence of emerging fodder enterprises supported by the WFP's food for asset (FFA) creation project. Thus, Isiolo County provided a suitable case to assess the emergence and role of various fodder producer groups undertaking fodder production and marketing as a result of the WFP's intervention. In the second stage, the three wards, Isiolo Central, Kinna and Oldonyiro, were purposively selected based on proximity to town and different livelihood zones. These wards present different dynamics in terms of fodder market accessibility by pastoralist communities. Isiolo Central is at the town centre; hence, the fodder market is slightly active due to emerging intensive dairy production enterprises. Kinna ward represents the agropastoral livelihood zone while Oldonyiro is purely a pastoral zone. In the third stage, a list of all the fodder group members was obtained from the master register of the FFA project which is under the custody of the group leaders. From this list, a random table was used to select a given number of individual members from each group proportionate to the group size, and the desired sample of 201 pastoralists was attained. The group leaders and AAK field monitors were consulted to help mobilize the selected members, who are representatives of both fodder groups and households, to be interviewed.

A household survey was conducted and semi-structured questionnaires administered through face-to-face interviews to collect information on household socio-economic characteristics and if they accessed relevant institutional factors over the 12 months preceding the study. Other key stakeholders such as representatives from the county government, NDMA and AAK were also engaged through key informant interviews to get more insights and broader understanding of the fodder value chain. Survey data was collected in June 2018, and the information on fodder production and marketing captured was for a year prior to the survey to cover the fodder produced in the previous planting season of March to May 2017.

\section{Data analysis}

Generally, market participation is defined as a household's engagement in the output and/or input market

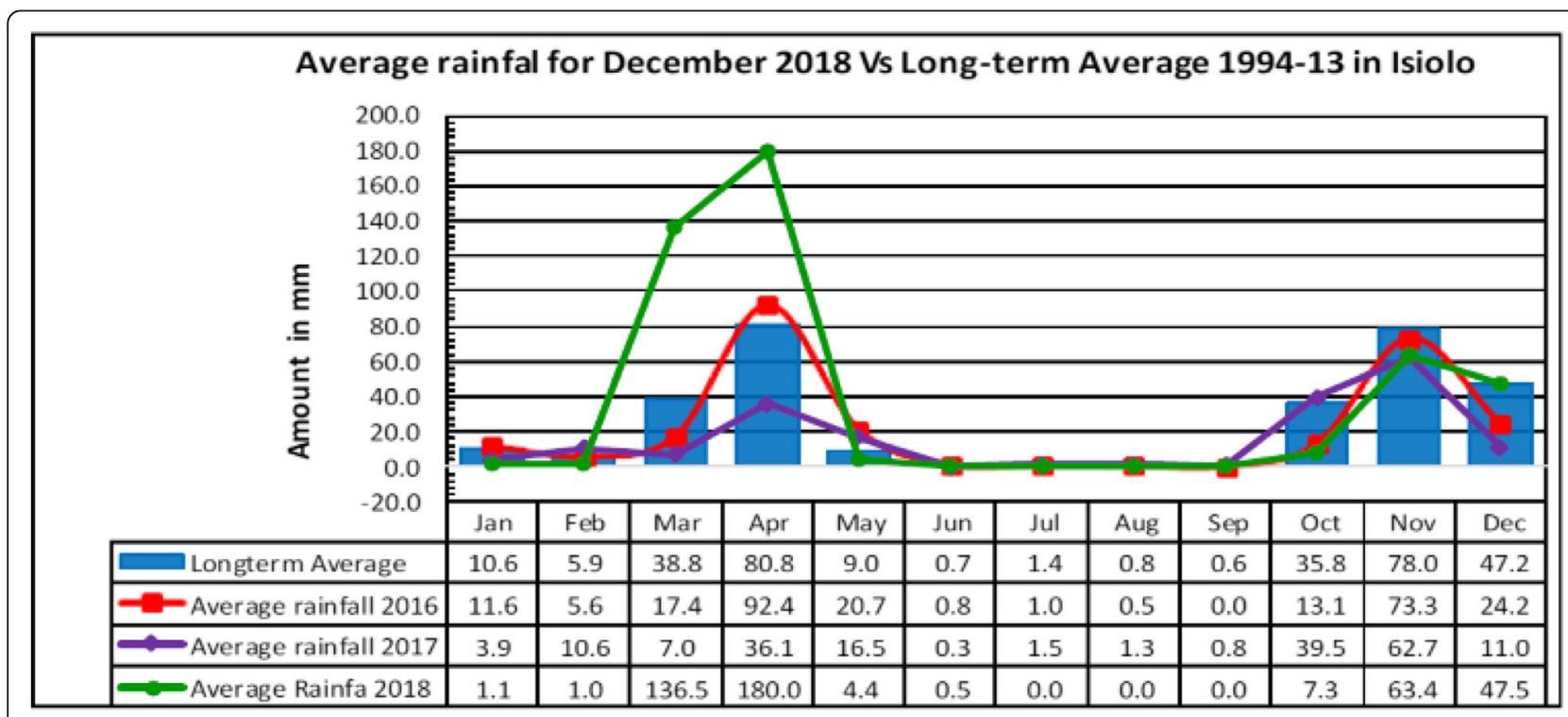

Fig. 3 A graph showing the monthly rainfall data for Isiolo County. Source: NDMA (2018) 
either as a buyer, seller of fodder or both. Fodder markets, in this case, refer to the fodder groups in Isiolo that are engaged in the production and selling of fodder. Therefore, it would have been ideally plausible to study fodder market participation at the group level since production and selling is being undertaken collectively. However, there were only 20 fodder producer groups actively undertaking substantial commercial fodder production in the study area, hence not a sufficient sample size for meaningful analysis. This necessitated an analysis at the individual level by focusing on households that are members of these fodder groups who are either buying fodder or not from their groups. Thus, fodder market participation in the context of this study refers to an individual pastoralist's decision to purchase fodder or not, for their own livestock within 1 year prior to the study. On the other hand, the quantity (bales) of fodder bought from the available markets was used as a relevant proxy for the intensity of market participation in the same period.

Pastoralists' fodder market participation behaviour was analysed as a two-step decision-making process. Most empirical studies that analysed households' market participation decisions as a two-step process applied Heckman's (1979) sample selection model (Vance and Buchheim 2005; Kabeto 2014). This is because the Heckman two-step model allows for different mechanisms to explain the participation decision and level of participation. The choice of this model is informed by its ability to relax Tobit's restrictive assumption that the zero values traded are because of a household's rational choice, even though prohibitive market barriers may be the factor restricting market participation (Heckman 1979; Komarek 2010). Moreover, a case of sample selection bias exists since the study focused on fodder group members in Isiolo County. The Heckman two-step model deals with a sample selection bias by computing the selection term, lambda $(\lambda)$, from the participation equation and including it as an explanatory variable in the second-stage regression to correct for self-selection. This is because the selection bias is regarded as an omitted variable and hence is corrected by this procedure (Wooldridge 2002).

\section{Model estimation}

The estimation of this model involves two stages as applied in an empirical study by Vance and Buchheim (2005). The first stage is referred to as the selection equation, which defines a binary choice indicating where the household falls (decision to buy fodder or not). It is estimated using a probit regression model to determine the likelihood that a household participated in the fodder markets. Let $B_{\text {ifodder }}=1$ represents a household that bought fodder whereas $B_{\text {ifodder }}=0$ is otherwise (nonbuyer). Therefore, the first step is specified as follows:

$$
\begin{aligned}
B_{\text {ifodder }}^{*} & =\beta X_{i}+U_{i} \\
B_{i \text { fodder }} & =1 \text { if } B_{\text {ifodder }}^{*}>0 \text { and } B_{\text {ifodder }} \\
& =0 \text { if } B_{\text {ifodder }}^{*} \leq 0
\end{aligned}
$$

where $B_{i f o d d e r}^{*}$ is a latent variable showing household satisfaction from purchasing fodder, $B_{i f o d d e r}$ is an indicator of market participation which takes the value of 1 for a household that buys fodder from the available market sources and 0 for those who do not buy, $X_{i}$ defines the characteristics of the household, $\beta$ is the vector of parameter coefficients to be estimated and $U_{i}$ is the error term with normal distribution.

The second stage involves estimating an ordinary least square (OLS) regression of the quantity (bales) of fodder bought conditional on market participation, $B_{i \text { fodder }}=1$ against the explanatory variables as shown below:

$$
Y_{i}=X_{i} \beta+\varepsilon_{i}
$$

where $Y_{i}$ is the quantity of fodder bought measured in the number of bales, $X_{i}$ is a vector of independent variables that determine the intensity of participation, $\beta$ is a vector of coefficients and $\varepsilon_{i}$ is the error term. As a result of the correlation of the error terms between probit and OLS regression, biased estimates are generated during estimation in the second stage with corr $(u, \varepsilon)$. Therefore, an inverse Mills ratio (IMR) was computed from the first stage of the probit regression and subsequently introduced in the OLS regression model with all other explanatory variables so as to correct for this bias (Komarek 2010), and the regression model extends to the following formulation:

$$
E\left(y_{i} / B_{i \text { fodder }}=1, x_{i}=\beta^{\prime} x_{i}+\rho \sigma_{\varepsilon} \lambda_{i}\right.
$$

where $x_{i}$ shows a vector of independent variables used to calculate the level of market participation after bias correction, $\beta^{\prime}$ is a vector of parameter coefficients to be estimated and $\sigma_{\varepsilon}$ and $\sigma_{u}$ represent random error terms of the outcome and selection equations, respectively. The $\lambda_{i}$ shows the IMR. Descriptive statistical analyses including means, standard deviations and crosstabulations, as well as an econometric model, were done using STATA software version 14.0.

According to literature, households' market participation decision is affected by numerous factors, including socioeconomic and institutional variables. Socio-economic factors are those individual attributes that explain why households behave differently (Jalang'o et al. 2018), and they include age, household size and gender for this study. The age of the household head/respondent has been used as a proxy for experience in most empirical studies and has 
been reported to have positive effects in some cases. Older farmers are said to have more experience and extensive social capital which probably reduces their marketing costs (Randela et al. 2008). Thus, age was hypothesized to have a positive influence on fodder market participation in this study. The age variable was measured as number of years and analysed as a continuous variable. Literature shows household size to be directly related to the household's demand for food and income to cater for other necessities (Elhadi et al. 2012; Gebremedhin et al. 2015). Similar studies noted that household size increases domestic consumption requirements and may render households more riskaverse, hence negatively influencing market participation (Randela et al. 2008; Muricho et al. 2015; Gebremedhin and Jaleta 2012). Hence, it was important to assess its influence on pastoralists' decision to purchase fodder. Gender determines access to, utilization and control over productive resources, particularly in the rural African context. This situation favours the male; hence, women-headed households are constrained by poor or no access to productive assets (Wasonga 2009). The study hypothesized the gender of the household head to have a negative influence on market participation, and it was captured as a dummy variable where a value of 1 was assigned to female-headed households and 0 to male-headed households. Studies have shown that individuals with more years of formal education are more likely to accept new ideas and innovations and hence are more likely to participate in commodity markets (Jalang'o et al. 2018). However, the level of education was excluded from the model in this study because of the lack of variation between the market participants and nonparticipants since most of them had no formal education.

Household asset holdings have also been recognized as key determinants of market participation in many empirical studies and include land size, livestock holding and off-farm income for this study. Land size depicts the household's productive asset ownership; therefore, households with larger parcels of land are more likely to allocate some portions for their own fodder production (Lugusa 2015). Studies have also shown that land can be used as collateral to access credit for investment in production and market participation (Randela et al. 2008; Komarek 2010). Thus, the influence of land size owned on market participation is expected to be positive directly or indirectly. The size of land owned was captured in hectares as a continuous variable, and the exact values as given by the respondent were used in the analysis. Herd size reflects the wealth status of the household in pastoral communities (Barrett et al. 2004), and is directly proportional to the demand for feed. Thus, herd size was expected to positively influence fodder market participation. This variable was measured in terms of the total number of livestock owned by a household converted into tropical livestock units (TLUs). The TLUs were computed as cattle $=1$, camels $=1$, donkeys $=0.8$, goats and sheep $=0.2$ and poultry $=0.04$ (WISP 2010). Livelihood diversification has been promoted in pastoral areas to augment subsistence from livestock that is vulnerable to high risks and uncertainty associated with climate-induced shocks (Elhadi et al. 2012). This variable was measured in terms of the proportion of off-farm income in the total household income. As noted by Muricho et al. (2015), off-farm activities provide households with extra income to participate in the market as buyers. Thus, a household with a higher proportion of off-farm income is hypothesized to participate in the fodder market as a risk mitigation strategy.

Institutional support services are considered requisites for households' market access and participation (Oluoch-Kosura 2010); they include access to extension services, market information, weather information, credit, and land tenure systems for this study. Extension services provide platforms for training and disseminating information on new technology or practices on fodder agronomy, harvesting and processing. Access to extension services is therefore expected to play a crucial role in influencing individual decisions regarding production, sale, income generation activities and eventually livelihood security (Elhadi et al. 2012; Gebremedhin et al. 2015). Access to market information is expected to significantly reduce transaction costs arising from information search and screening and thus encourage market participation (Alene et al. 2008; Randela et al. 2008). Pastoralists with access to weather information on early warning signs are expected to purchase fodder as a drought preparedness strategy. These variables were captured as dummies and assessed based on if a household had access to them, from various sources available, in the last year prior to the survey. Empirical studies have noted access to credit as an enabler of farmer's participation in agricultural commodity markets (Alene et al. 2008; Martey et al. 2012). This variable was coded as a dummy taking a value of 1 if the household had access to any form of credit services in the last 1 year prior to the survey and 0 otherwise. Credit access was anticipated to positively influence household participation in fodder markets.

The insecurity of land tenure, both in terms of property ownership and resource access, has been acknowledged as one of the key constraints to the adoption of innovative and sustainable land management practices such as the use of enclosures and fodder growing in drylands (AU-IBAR 2012; Muricho et al. 2017). This variable was assessed based on if the household had a title deed to land occupied and was anticipated to have a positive influence on market participation. The study area (Isiolo) is prone to climate-induced shocks such as droughts, floods, diseases and conflicts over natural resources. These shocks are experienced by all households 
at the same time but at varying degrees; hence, this factor was assessed in terms of the number of shocks a household was exposed to over the last 10 years. The number of shocks experienced by households is expected to positively influence participation in fodder markets (Lugusa 2015). The dummy variable for the ward (location) was also included in the analysis to assess its influence on household decision to purchase fodder, so as to capture the potential effect of differential infrastructure levels across localities and relative geographic isolation from the markets.

The study hypothesized that institutional factors such as access to extension, market information, weather information, credit services and tenure system do not affect pastoralists' decisions to buy fodder. Household characteristics, such as age, gender and household size, and asset variables like land size, herd size and off-farm income, were also hypothesized not to influence pastoralists' decision to purchase fodder.

\section{Results and discussions}

Socio-demographic characteristics of the sampled respondents

Some of the key characteristics of the pastoralists interviewed are summarized in Tables 1 and 2 .

Results showed that the average age of the respondents in the sample was 38 years, with no significant age difference between the fodder buyers and non-buyers. This implies that fodder group members are mainly middleaged pastoralists, and this age is considered a productive stage of life. This concurs with the Isiolo County integrated development plan (CIDP), which stated that the county's economically active labour force falls in the age bracket of 15 to 64 years (Republic of Kenya 2013). The mean household size for the entire sample was about 7 persons, which is slightly higher than the Isiolo's and Kenya's national mean of 5 and 4 persons per household, respectively (KNBS 2019). This might be associated with the polygamous culture that is commonly practiced among the pastoralists. The average number of years of formal education was 2 years, indicating a high illiteracy level among the pastoralists in Isiolo County. The mean household size and years of formal education of fodder buyers and non-buyers were not significantly different.

The average land size holding was approximately 3.3 ha for the sample. However, households that were not participating in fodder markets had slightly larger average land sizes compared to their counterparts though the variations are not statistically significant. This could mean that households with larger land sizes can grow their own sufficient fodder and hence may not need to purchase fodder from the market. The average TLU was 11.32, showing the significance of holding a relatively large herd to pastoralists as they are a store of wealth and social status in the society (Barrett et al. 2004; WISP 2010). Pastoralists with large herd size are expected to source for alternative feeds through buying fodder in order to complement natural grazing resources. Also, livestock sales provide pastoralists with the liquidity necessary to purchase inputs such as fodder and veterinary services.

The household mean annual total income was about KES 16,512 (USD 157.26) which translates to KES 46 (USD 0.44) per day, implying that most sampled households live below the minimum poverty threshold of USD 1.9 per day as defined by the World Bank in 2015 (Jolliffe and Prydz 2016). This is because the FFA project targeted the very vulnerable people who predominately depended on food aid. In addition, the average off-farm income was KES 6111 (USD 58.2) and mainly sourced from retail businesses and casual jobs. Results show a significant difference in herd size, total income and off-farm between the two groups. The households with more livestock are noted to have low

Table 1 Respondents' socio-economic characteristics

\begin{tabular}{lllll}
\hline Variable & Pooled & \multicolumn{2}{l}{ Mean } & \\
\cline { 3 - 4 } & & $\begin{array}{l}\text { Market participants } \\
(\boldsymbol{n}=116)\end{array}$ & $\begin{array}{l}\text { Non-participants } \\
(\boldsymbol{n}=85)\end{array}$ & $\boldsymbol{p}$ value for the test of statistical differences \\
\hline Age of respondents (years) & $38.33(11.52)$ & 39.47 & 36.78 & 0.101 \\
Household size (numbers) & $6.42(2.67)$ & 6.59 & 6.18 & 0.287 \\
Years of formal schooling & $2.00(3.61)$ & 2.08 & 1.89 & 0.723 \\
Land size owned (ha) & $3.28(4.94)$ & 2.84 & 3.87 & 0.145 \\
Annual household income (KES) & $16,512.00(31,496.00)$ & $13,067.52$ & $21,211.71$ & $0.070^{*}$ \\
Tropical livestock units (TLUs) & $11.32(13.25)$ & 13.60 & 8.2 & $0.004^{* * *}$ \\
Annual off-farm income (KES) & $6110.96(29,807.89)$ & 2670.00 & 10,807 & $0.056^{*}$ \\
Number of shocks experienced & $2.58(1.49)$ & 3.25 & 1.67 & $0.000^{* * *}$ \\
\hline
\end{tabular}

Standard deviations are in parentheses. Source: survey data (2018)

$\mu_{1}$ USD was equivalent to KES 105 at the time of the survey

Statistical significance levels: ${ }^{* * *} p<0.01$ and ${ }^{*} p<0.1$ 
Table 2 Institutional factors

\begin{tabular}{|c|c|c|c|c|}
\hline \multirow[t]{2}{*}{ Variable } & \multirow[b]{2}{*}{ Pooled } & \multicolumn{2}{|l|}{ Frequency (\%) } & \multirow[b]{2}{*}{$\begin{array}{l}\boldsymbol{p} \text { value for the test } \\
\text { of statistical differences }\end{array}$} \\
\hline & & $\begin{array}{l}\text { Market participants } \\
(\boldsymbol{n}=116)\end{array}$ & $\begin{array}{l}\text { Non-participants } \\
(\boldsymbol{n}=85)\end{array}$ & \\
\hline Gender of respondents ( $1=$ male, $0=$ female) & 91.04 & 57.92 & 55.56 & 0.846 \\
\hline Access to extension services ( $1=$ yes, $0=$ no $)$ & 32.84 & 83.33 & 16.67 & $0.000^{* * *}$ \\
\hline Access to weather information ( $1=$ yes, $0=$ no $)$ & 54.73 & 76.36 & 23.64 & $0.000^{* * *}$ \\
\hline Access to market information ( $1=$ yes, $0=$ no) & 28.36 & 94.74 & 5.26 & $0.000^{* * *}$ \\
\hline Access to credit services $(1=$ yes, $0=$ no $)$ & 43.28 & 71.26 & 28.74 & $0.001^{* * *}$ \\
\hline Membership to development groups $(1=$ yes, $0=$ no $)$ & 39.3 & 74.68 & 25.32 & $0.000^{* * *}$ \\
\hline \multicolumn{5}{|l|}{ Land tenure systems } \\
\hline Private with title deed & 5.97 & 91.67 & 8.33 & $0.000^{* * *}$ \\
\hline Private with allotment letters & 8.46 & 17.65 & 82.35 & $0.000^{* * *}$ \\
\hline Communal & 85.57 & 59.3 & 40.7 & $0.000^{* * *}$ \\
\hline
\end{tabular}

Source: survey data (2018)

Statistical significance levels: ${ }^{* *} p<0.01$

off-farm and total income and are fodder buyers. This could be because livestock keeping is labour-intensive and time-consuming and thus limits the household's engagement in off-farm activities. On the other hand, those with less livestock have sufficient time to invest in offfarm enterprises and hence have more off-farm income. Pastoralists with large herds are expected to buy fodder to sustain their livestock during dry spells. Pastoralists' production and livelihood systems are prone to climateinduced shocks, which occur simultaneously, hence making them more vulnerable. This is evidenced by the finding that respondents are exposed to at least 3 different shocks on average over the last 10 years. The major shocks noted were droughts, livestock diseases and conflicts. These shocks force pastoralists to adapt through fodder purchases; hence there are significant variations in the number of shocks experienced between the households who buy fodder as compared to their counterparts.

The results in Table 2 also indicate that fodder producer groups were dominated by women, with over $90 \%$ of respondents being female. Pastoral women play a significant role in livestock management as they are often tasked with the responsibility of going up hills and mountains to collect pasture for the home-stay lactating livestock. This burden increases during the dry seasons and becomes strenuous, demanding more time and labour (Kaufmann et al. 2012). Therefore, the higher proportion of women engaging in fodder producer groups could be attributed to the proximity of the group farms to their homesteads and their availability to undertake group farm activities.

This corroborates the findings of Peishi (2018), which showed that women's engagement in FFA projects is motivated by the proximity of FFA activities to their home, the need to improve their livelihoods and benefits associated with the assets created. This is contrary to pastoral men who are widely known for their high preference to engage in large-scale commercial livestock-based activities (Place and Kariuki 2005). Thus, pastoral men have less interest in fodder production, which is still small-scale with limited commercialization. Furthermore, participation in FFA programmes is reported to support women's empowerment through: women playing key leadership roles in the groups' committees; expanding their social networks; providing opportunities for income generation; and improved technical skills and confidence (Peishi 2018). Likewise, strong womens' participation in community-based rangeland rehabilitation is considered instrumental in building the resilience of dryland communities and the sustainability of the interventions (AU-IBAR 2012).

Generally, the households that participate in fodder markets had significantly more access to institutional support services such as credit facilities, extension, market information and weather information compared to non-participants. This is plausible because these factors are widely cited in the literature as positive determinants of the market participation behaviour of households. Access to extension services was however low with only a third of the respondents having access, mainly from various individual non-governmental organizations (NGOs) and the County government. Extension services enable members to realize the benefits of having a constant supply of fodder through group training and thus members more likely to buy fodder in preparation for dry seasons. This underscores the importance of extension services to the pastoralists' communities.

More than half of the respondents had access to early warning information regarding changes in weather conditions, mainly from the traditional elders who disseminated through home visits and in local meetings (barazas). Pastoralists rely heavily on various traditional 
weather forecast mechanisms to predict possible climate outlook in the near future (Barrett et al. 2004). Access to weather information enables pastoralists to plan ahead in order to mitigate livestock deaths due to drought periods. The results further indicate that at least a third of the respondents also belonged to other developmental groups such as women and youth groups, besides fodder groups. Households' access to credit was about $43 \%$ but solely from women groups as opposed to formal financial institutions. Social groups play a critical role among pastoralists as they facilitate access to funds and loan services through merry-go-rounds and table-banking initiatives, respectively. It also enhances access to markets, trainings and business skills (Place and Kariuki 2005). Over $80 \%$ of the respondents held communal tenure over the land occupied with only $6 \%$ and $8 \%$ claiming private ownership with formal title deeds and temporary allotment letters, respectively. This concurs with the assertion in Isiolo CIDP that over $80 \%$ of the land in Isiolo is communally owned but held under the trusteeship of the county government. A large share of the land in Isiolo is being utilized by pastoralists for grazing while the remaining parts are used by agro-pastoralists for crop farming (Republic of Kenya 2013).

\section{Fodder production and marketing in Isiolo County}

As shown in Table 3, the groups each produced an average of 57 bales of fodder and $35 \mathrm{~kg}$ of grass seeds in the last planting season. The groups noted that 2017 was marred with a long dry spell; hence, low production was realized. Out of which, an average of 44 bales of fodder and $6 \mathrm{~kg}$ of seeds were sold. The groups use wooden boxes and manually compress the dried hay to make a bale which is equivalent to $20 \mathrm{~kg}$.

The common grass species planted were African foxtail (Cenchrus ciliaris), Maasai love grass (Eragrotis superba) and African horsetail (Chloris roxburghiana) introduced by the University of Nairobi's African Drylands Institute for Sustainability. Approximately 58\% of the sampled households have bought fodder from various market sources, and the average volume bought by a household was 10 bales in the last year. Results also showed that over $80 \%$ of the buyers sourced from their own fodder groups. This implies that the group members acted as the primary marketing channel for the fodder produced by their groups. Conversely, 10\% bought from the traders in the market and the rest from other fodder groups in the area as a secondary market. The traders in the livestock markets sourced hay from within and outside the county, especially hay made from wheat stalk residues from Nanyuki and Laikipia areas, and sold to livestock keepers during market days.

The fodder purchasing prices varied across the different market outlets though not statistically significant (Table 3). However, it was noted that the fodder markets in the surveyed areas are niche and vibrant in the dry season. Also, this only represents the prices in the surveyed localities which are relatively isolated and distant from Isiolo town, hence having relatively lower prices. The fodder groups sold to their members at a relatively lower price of about KES 280 (USD 2.67) compared to other consumers. The low fodder price was one of the benefits enjoyed by group members, and it acted as an incentive for their commitment to the groups. Fodder from own groups was also preferred because of the group farm's close proximity to members' homesteads. This implies minimum transportation costs incurred as buyers carried fodder on their shoulders/back.

In terms of payment method, nearly $70 \%$ of the participants paid cash on the spot, $24 \%$ paid later while the rest purchased fodder on a credit basis. This flexibility in payment was also an additional benefit enjoyed by members who bought fodder from their own groups. For the secondary markets, all buyers paid cash upon receipt of

Table 3 Fodder production and sale by producer groups

\begin{tabular}{|c|c|}
\hline Variables & Statistic $(\boldsymbol{n}=20)$ \\
\hline Average quantity of fodder produced (bales*) & $57(90)$ \\
\hline Quantity of fodder sold (bales) & $44(90)$ \\
\hline Average quantity of fodder bought by households (bales) & $10(33)$ \\
\hline \multicolumn{2}{|l|}{ Average selling price for hay ${ }^{\mu}(\mathrm{KES})$} \\
\hline Group members & $283(44)$ \\
\hline Neighbours & $317(113)$ \\
\hline Traders & $367(116)$ \\
\hline Average quantity of grass seed produced (kg) & $35(119)$ \\
\hline Average quantity of grass seed sold (kg) & $6(16)$ \\
\hline Average selling price for grass seeds ${ }^{\mu}$ (KES) & $700(141)$ \\
\hline
\end{tabular}

Standard deviations in parentheses; $n$ number of producer groups surveyed; ${ }^{\mu} 1$ USD $=$ KES 105 . Source: survey data (2018)

${ }^{*} \mathrm{~A}$ bale is equivalent to $20 \mathrm{~kg}$ 
the fodder. Over $70 \%$ of the traded fodder was processed in the form of baled hay, while the rest was in the form of freshly cut green pastures and standing pastures on the farm. At the time of the survey, the groups had several bags of seeds and baled hay in the store and were planning to sell them. They also had mature standing pasture in the group farms ready for harvest before the onset of the rainy season in August.

\section{Factors influencing pastoralists' participation and intensity of participation in fodder markets}

The parameter estimates for the two-step Heckman model are presented in Table 4.

The continuous variables were transformed into logarithm form to reduce outliers (Wooldridge 2002). Results show that the rho, which measures the correlation between the errors in the selection and outcome equations, is positive and the Wald chi-square is highly significant at $1 \%$. This implies a strong correlation between the decision to buy fodder and the quantity of fodder bought. The inverse Mills ratio (IML/lambda) term was positive and significant at $10 \%$ suggesting that the error terms in the selection and outcome equations are positively correlated. These results confirm that the decision to participate in markets and the intensity of market participation are interrelated and modelling them as separate processes would yield misleading results. The marginal effects for the selection equation were computed for ease of interpretation.

Pastoralists' access to market information was positive and significantly associated with household participation in the fodder market. Having access to market information increases the probability of respondents purchasing fodder by $47 \%$. This is because these households received information related to prevailing fodder prices, demand, supply and alternative market outlets majorly from their fodder groups. Therefore, they incurred lower transaction costs associated with information searching and transportation cost since most group farms are close to their homesteads. This concurs with Otieno (2011) who noted that prior market information is critical because it could inform respondents' decisions to buy fodder, choice of market outlets and when to buy fodder for storage.

Access to weather information (early warning signs) positively influenced pastoralists' participation in fodder markets at 5\% level of significance. The marginal effect indicates that a shift from lacking access to weather information to having access increases the likelihood of a pastoralist buying fodder by $19 \%$. This is plausible because pastoralists' access to reliable early warning systems enhances their early preparedness and adoption of drought-mitigation strategies such as prior purchase and storage of livestock feeds. This result concurs with Barrett et al. (2004), who noted that access to accurate and timely climate forecasts regarding the start date for the rainy season, the volume of rainfall expected and the end date has a potential influence on pastoralists' mobility patterns and marketing strategies. On the other hand, access to weather information had no significant influence on the quantity of fodder bought.

As expected, access to credit was statistically significant at $1 \%$ level and positively associated with

Table 4 Two-step Heckman model results for fodder market participation

\begin{tabular}{|c|c|c|c|c|}
\hline \multirow[t]{2}{*}{ Variable } & \multicolumn{2}{|c|}{ Decision to buy fodder equation } & \multicolumn{2}{|c|}{ Quantity of fodder bought equation } \\
\hline & Coef. & $d y / d x$ & Coef. & Std. error \\
\hline Access to market information $(1=$ yes; $0=$ no) & $1.329^{* * *}$ & 0.474 & - & - \\
\hline Access to weather information $(1=$ yes; $0=$ no $)$ & $0.526^{* *}$ & 0.188 & -9.927 & 7.412 \\
\hline Access to extension services ( $1=$ yes; $0=$ no) & 0.212 & 0.076 & 3.442 & 5.991 \\
\hline Access to credit $(1=$ yes; $0=$ no $)$ & $0.732^{* * *}$ & 0.261 & - & - \\
\hline Land tenure ( 1 = private; 0 = communal) & $-1.190^{* * *}$ & -0.425 & $-20.43^{* *}$ & 9.543 \\
\hline Number of shocks experienced (in the last 10 years) & $0.470^{* * *}$ & 0.168 & $5.801^{* *}$ & 2.423 \\
\hline Log age of respondent (years) & $0.834^{*}$ & 0.298 & 13.512 & 9.838 \\
\hline Sex of household head ( 1 = female; 0 = otherwise) & $-0.454^{*}$ & -0.162 & 5.233 & 5.779 \\
\hline Log household size (numbers) & 0.125 & 0.044 & -8.345 & 6.222 \\
\hline Log land size owned (ha) & 0.154 & 0.055 & -1.301 & 3.611 \\
\hline Tropical livestock units (TLUs) & 0.0042 & 0.001 & $1.506^{* * *}$ & 0.181 \\
\hline Proportion of off-farm income & $-0.914^{* *}$ & -0.326 & 3.326 & 11.002 \\
\hline Ward (town as base category) & $0.520^{* *}$ & 0.185 & 7.709 & 5.448 \\
\hline Constant & $-6.312^{* * *}$ & - & $-86.39^{* *}$ & 42.054 \\
\hline
\end{tabular}

Sample $(n)=201$ (censored observations $=85$, uncensored observations $=116$ ). Rho $=0.618$, sigma $=26.626$, lambda $=16.451 *$, Wald chi-square $(11)=91.930$, prob $>$ chi-square $=0.000$. Source: survey data (2018)

***Significance levels at $1 \%$; ${ }^{*}$ significance levels at $5 \% ;{ }^{*}$ significance levels at $10 \%$ 
pastoralists' participation in the fodder market. Household's access to credit increases the probability of buying fodder by $26 \%$. This is because credit access enhances the purchasing power of the pastoral households to buy inputs such as feeds, veterinary medicines and minerals for livestock production. This concurs with the findings of previous studies that found that credit access reduces transaction costs in both input and output markets and enables farmers to purchase inputs such as land, seeds and fertilizer to expand production and subsequently market participation (Randela et al. 2008; Jalang'o et al. 2018). Similarly, Shibia (2018) noted that the use of financial instruments including credit, savings and insurance provides market-based coping mechanisms to cushion households from external shocks, and they tend to be more effective compared to informal coping mechanisms.

The land tenure security had a negative and significant influence on both the decision and intensity of market participation at $1 \%$ and $5 \%$, respectively. This implies that a shift from communal to private land ownership reduces the likelihood of the household buying fodder by $42 \%$. This is reasonable because secure land tenure enables households to enjoy exclusive rights to access, use, manage and derive benefits from their land, and thus, they can produce adequate fodder for their livestock. On the other hand, communal land ownership discourages individual pastoralists to produce own fodder, thus forcing them to buy from the available market outlets. This is expected since Isiolo County is predominantly composed of communal lands. This finding is similar to observations in previous studies, which acknowledged insecurity of land tenure as a key deterrent to the adoption of sustainable land management practices in drylands (AU-IBAR 2012; Muricho et al. 2017).

As anticipated, the number of shocks experienced significantly and positively influenced household participation in fodder markets and the quantity of fodder bought. The marginal effect estimate indicated that a unit increase in the number of shocks experienced increased the likelihood of buying fodder by $17 \%$ and the quantity of fodder bought by $6 \%$. This was expected because most of the respondents were affected by several shocks occurring concurrently; hence, they had suffered massive losses of livestock and livelihood assets. Pastoralist communities often tend to keep large herds of livestock as a means of asset accumulation to safeguard against future shocks. However, pastoral production systems are highly susceptible to low and variable rainfall, diseases and resourcebased conflicts (Barrett et al. 2004). Therefore, it is only rational for the pastoralists to learn from these experiences, buy and store fodder in preparedness for drought seasons to mitigate losses. These finding corroborates Lugusa et al. (2016) who observed that pastoral households who had experience with droughts were more likely to join fodder groups to easily access livestock feeds.

As hypothesized, the age of the respondent positively and significantly influenced the probability of market participation but insignificantly affected the quantity of fodder bought. The marginal effects showed that older pastoralists had a higher probability of buying fodder for their livestock by $30 \%$. A plausible explanation could be that older households have accumulated vast experience in livestock production and management over the years. Therefore, they tend to be more cautious and willing to purchase fodder and store in preparedness for long dry spells. This result corroborates that of Muricho et al. (2017) who observed that older household heads were more resilient to climate-induced shocks because of experience accrued over the years. Also, age influences household's access to and utilization of productive resources, which facilitates the accumulation of wealth in form of livestock over the years and thus has more demand for fodder (Lugusa 2015; Ochago et al. 2017).

On the other hand, the gender of the household head had a negative and significant effect on the households' fodder market participation decisions, however insignificant in the intensity of participation. This implies that being female and household head significantly reduced the likelihood of buying fodder by $16 \%$. This is because key assets and resources such as land, livestock, water and cash in the pastoral communities are generally controlled by men (Republic of Kenya 2015). Thus, most crucial household decisions concerning production and marketing are made by men as well (Muricho et al. 2017). Additionally, female-headed households are generally reported to be poor with limited productive assets and hence cannot afford to buy fodder. As noted by Opiyo et al. (2014), female-headed households were less resilient mostly because of gender bias in resource allocation and control among pastoralists. Some market participation studies have also noted that male-headed households are considered resource endowed hence participate more in the markets than their female counterparts (Jagwe 2011; Gutierrez 2003) and that female-headed households are more likely to participate in agricultural markets as net buyers (Bellemare and Barrett 2006).

Consistent with prior expectation, herd size was found to have a positive and significant influence on the quantity of fodder bought, at $1 \%$ significant level. This is because ownership of livestock provides pastoralists with the leverage to invest in purchasing fodder since the number of livestock is directly proportional to the feed demands (Lugusa 2015). Also, with the shrinking natural pastures due to climate change and variability, pastoralists opt to enhance feed availability and quality through feed purchases from the market (Omollo et al. 2018). Besides, it is widely acknowledged that livestock serves 
as a capital asset to pastoralists and hence can be easily liquidated to cash to meet expenditure needs such as food and livestock feeds (Barrett et al. 2004). The proportion of off-farm income to total income was found to have a negative and significant influence on the household's decision to participate in fodder markets. As indicated by the marginal effects, a unit increase in the household's off-farm income reduced the likelihood of pastoralists' buying fodder by $33 \%$. Consistent with prior discussions, households with a more off-farm income had low herd size and hence had less demand for fodder.

The study also included the locations (wards) as dummies to assess their influence on fodder market participation. Results indicate that location positively influences fodder market participation but only significant for the first stage. This implies that those who are closer to the town centre are more likely to purchase fodder by $19 \%$ due to the easy accessibility to fodder markets in town. Thus, the role of remoteness and geographic isolation as a key obstacle to market participation is confirmed by this finding. Access to extension services had a positive sign as expected, though insignificant in influencing both market and intensity of participation. The possible explanation for this is because only a third of the respondents had access to extension services, the majority of whom acknowledged infrequent visits and communication barriers as major challenges faced. Furthermore, Isiolo County is characterized by weak extension services due to inadequately trained personnel and limited resources coupled with poor availability and distribution of inputs (Republic of Kenya 2013). These factors bear a negative influence on household access to institutional support services such as training and improved technology. Household size and land size both have expected signs though their influence on market participation was statistically insignificant. However, their inclusion was found to improve the Heckman two-step model, indicating that their association with other explanatory variables contributes jointly to explaining pastoralists' fodder market participation behaviour.

\section{Conclusion and policy recommendations}

This study assessed the socio-economic and institutional factors influencing pastoralists' participation in fodder markets for livelihood resilience in Isiolo County of Kenya. Generally, the findings of the study illustrated that pastoralists have low development indices as revealed by low literacy level and low per capita income. Thus, more concerted efforts and investment by both the county and national governments are required to enhance access to and utilization of both formal and adult education especially for the pastoral women. The results further indicated the existence of commercial fodder markets in Isiolo County and fodder producer groups was the dominant market utilized.

Additionally, pastoralists' access to key institutional services such as extension, credit, market and early warning information was also limited. However, the results showed that institutional factors such as credit, market information, weather information and communal land tenure system are the most important factors that encourage and promote pastoralists' participation in fodder markets. On the other hand, the intensity of market participation was determined by access to weather information, communal land tenure system, TLUs and number of shocks experienced. These observations underscore the significance of pastoralists' access to requisite institutional and support services in strengthening their access to and participation in wellfunctioning markets. This will stimulate the household's investment in alternative livelihoods to better manage climate-induced shocks.

Credit facilities were solely sought from informal sources like women groups, indicating a big gap in terms of pastoralists' access to loans from formal financial institutions that can offer substantial credit facilities. The county government should strengthen access to socially inclusive financial services by undertaking strategic partnerships with relevant financial service providers. The growth in mobile banking platforms such as $M$-pesa and $M$-shwari services also provides more opportunity for accessing affordable credit facilities. For instance, pastoralists can save money in an M-shwari account and access credit through their phone without undergoing the tedious process in mainstream banking.

The findings also revealed the importance of private tenure systems in facilitating households' adoption of adaptive strategies like fodder production on their farms. This calls for the county government to fast track the land registration process to facilitate formal land titling. This will enhance pastoralists' adoption of more innovative land use practices such as fodder production and marketing for sustainability. Provision of extension services, through organizing platforms such as fodder conferences and exhibitions for awareness creation and sharing of ideas and experiences, can play a vital role in the sensitization of pastoralists on the value of purchasing fodder and storage in preparation for dry seasons. Moreover, household attributes such as age and off-farm income significantly influenced fodder market participation. Results also indicated that women were dominant participants in fodder producer groups. However, being female and as well as the household head reduces the likelihood to participate in the fodder market as a buyer due to low resource endowment. This calls for womens' empowerment by encouraging them to seek for loan facilities collectively, through fodder groups, since social 
capital is considered as a form of collateral. The county may also boost the women's table-banking initiative by ensuring easy access to development funds such as women and youth funds.

Overall, this study has demonstrated that it is possible to change the orientation of pastoralists from a culturally-based system that abhors investment in fodder to a more commercially focused approach if interventions are designed in consideration of local needs and perspectives. This implies the need to embrace a consultative approach in promoting the uptake of new technologies such as fodder cultivation and seeking input provision mechanisms and marketing models that fit within local contexts as opposed to externally-driven frameworks for sustainability.

\section{Limitations and suggestions for future research}

The present study was constrained by data limitation; being a cross-section study, it only covered fodder production and marketing in the year prior to the study and hence was not able to explain the seasonality aspect. It was also beyond the scope of this study to assess the quality of fodder purchased. Future research could focus on analysing the fodder supply and prices by considering data over a longer period, thus accounting for seasonality, and also assess the relationship between fodder quality and prices. Additionally, the short duration of this study did not allow for a detailed assessment of the fodder markets in the whole County; hence, the scope was restricted to the fodder producer groups under FFA project only in the surveyed locations. Moreover, dealing with groups raises the issue of self-selection; hence, the results may not apply to the entire county, including those not in groups.

\section{Abbreviations}

AAK: Action Aid Kenya; ASALs: Arid and semi-arid lands; AVCD-

LC: Accelerated Value Chain Development-Livestock Component; AU: African Union; AU-IBAR: African Union Inter-African Bureau on Animal Research; CIDP: County integrated development plan; FAO: Food and Agriculture Organization of the United Nations; FFA: Food for assets;

IGAD: Intergovernmental Authority on Development; KALRO: Kenya Agricultural and Livestock Research Organization; KES: Kenya Shillings; KIPP RA: Kenya Institute for Public Policy Research and Analysis; KNBS: Kenya National Bureau of Statistics; KVDA: Kerio Valley Development Authority; NDMA: National Drought Management Authority; RAE: Rehabilitation of Arid Environments Trust; REGAL-AG: Resilience and Economic Growth in the Arid Lands-Accelerated Growth; TLUs: Tropical livestock units; UN: United Nations; USD: United States Dollars; USAID: United States Agency for International Development; VCl: Vegetation Condition Index; WFP: World Food Programme; WISP: World Initiative for Sustainable Pastoralism

\section{Acknowledgements}

The authors thank the African Economic Research Consortium (AERC) for partially funding this research work. The authors also wish to thank the research network Triple L's research project "Escaping the pastoralist paradox in the face of climate change", funded by the Swedish Research Council for partial financial support. We also thank the data enumerators for their committed effort to collect reliable data during fieldwork and the fodder group members in Isiolo for their time and valuable contribution to this study.

\section{Authors' contributions}

SMS (first author) developed the concept, designed the study, collected the data, analysed and interpreted the data and prepared the manuscript for submission to this journal. DJO, JN and SMM contributed to the conception and design of the study and provided technical and intellectual support during analysis, interpretation of the data and manuscript drafting. SMM also facilitated the acquisition of funds for the study from the research network Triple L (Land, Livestock, and Livelihoods) as the coordinator. This final manuscript was submitted with the approval of all the supervisors. The authors read and approved the final manuscript.

\section{Funding}

Partial funding was received from the African Economic Research Consortium (AERC) (https://aercafrica.org/) as part of the Masters scholarship awarded to the corresponding author. However, I declare that AERC did not contribute to the study from design to the end. The research network Triple L (Land, Livestock, and Livelihoods) (http://www.triplel.se/) partially funded the data collection, contributed to the conception and design of the study and provided technical and intellectual support during analysis, interpretation of the data and manuscript drafting, through the fourth author (SMM).

\section{Availability of data and materials}

The datasets used and/or analysed during the current study are available from the corresponding author on reasonable request.

Ethics approval and consent to participate

Not applicable

\section{Consent for publication}

Not applicable

\section{Competing interests}

The authors declare that they have no competing interests.

\section{Author details}

${ }^{1}$ Department of Agricultural Economics, University of Nairobi, P.O. Box 29053-00625, Nairobi, Kenya. 'Department of Land Resource Management and Agricultural Technology, University of Nairobi, P.O. Box 29053-00625, Nairobi, Kenya.

Received: 9 September 2019 Accepted: 8 April 2020

Published online: 20 August 2020

\section{References}

Alene, D.A., M.V. Manyong, G. Omanya, D.H. Mignouna, M. Bokanga, and G. Odhiambo. 2008. Smallholder market participation under transaction costs: Maize supply and fertilizer demand in Kenya. Food Policy 33: 318-328.

African Union Inter-African Bureau on Animal Research (AU-IBAR). 2012. Rational use of rangelands and fodder crop development in Africa. Monographic Series Number 1.

Ayele, S., A. Duncan, A. Larbi, and T. Khanh. 2012. Enhancing innovation in livestock value chains through networks: Lessons from fodder innovation case studies in developing countries. Science and Public Policy 39 (3): $333-$ 346

Barrett, C., McPeak, J., Luseno, W., Little, P., Osterloh, S., Mahmoud, H., and Gebru, G. 2004. Pastoralist livestock marketing behaviour in northern Kenya and southern Ethiopia: An analysis of constraints limiting off-take rates. Retrieved from https://ssrn.com/abstract=611064 or https://doi.org/10.2139/ssrn. 611064. Accessed 20 June 2018.

Bellemare, M., and C. Barrett. 2006. An ordered Tobit model of market participation: Evidence from Kenya and Ethiopia. American Journal of Agricultural Economics 88 (2): 324-337.

Berhe, M., Hoag D., Tesfay, G., Oniki, S., and Kagatsume, M. 2016. Effects of adaptation to climate change on income of cattle owners in the pastoral and agro-pastoral communities of Northern Ethiopia. Paper read at the $5^{\text {th }}$ International Conference of African Association of Agricultural Economists, 23-26 September. Addis Ababa, Ethiopia. 
Coppock, D., S. Desta, A. Wako, I. Aden, G. Gebru, S. Tezera, and C. Tedecha. 2006. Women's groups in arid northern Kenya: Origins, governance and roles in poverty reduction. In In Invited paper presented a Policy Research Conference on Pastoralism and Poverty Reduction in East Africa, 27-28 th June.

Cormack, Z. 2016. The promotion of pastoralist heritage and alternative 'visions' for the future of Northern Kenya. Journal of Eastern African Studies 10 (3): $548-567$

Elhadi, A., D. Nyariki, V. Wasonga, and W. Ekaya. 2012. Factors influencing transient poverty among agro-pastoralists in semi-arid areas of Kenya. African Crop Science Journal 20 (1): 113-122.

Gebremedhin, B., and Jaleta, M. 2012. Market Orientation and Market Participation of Smallholders in Ethiopia: Implications for Commercial Transformation. A research paper presented at the International Association of Agricultural Economists (IAAE) Triennial Conference, Foz do Iguacu, Brazil, 18-24 August.

Gebremedhin, B., D. Hoekstra, A. Tegegne, K. Shiferaw, and A. Bogale. 2015. Factors determining household market participation in small ruminant production in the highlands of Ethiopia. LIVES Working Paper 2. Nairobi: ILRI Retrieved from: https://hdl.handle.net/10568/65204. Accessed 3 Feb 2018.

Gutierrez, M. 2003. Macro economics: Making gender matter concepts, policies and institutional change in developing countries. London: Zed Books.

Heckman, J. 1979. Sample selection bias as a specification error. Econometrica 47: 153-161.

IGAD. 2017. Proceedings of a Regional Workshop on good practices in fodder and fodder seed production and marketing for increased private sector investment held on $6^{\text {th }}$ to 7 th, April at Pelican Resort, Elementaita, Kenya. Retrieved from: https://icpald.org/wp-content/uploads/2018/05/IGAD-Fodderand-Fodder-seed-regional-workshop-proceedings-13-July-2017-No-Track.pdf. Accessed 29 May 2019.

Iruata, M., V. Wasonga, and R. Ngugi. 2015. Economic contribution of the pastoral meat trade in Isiolo County, Kenya: Findings from Oldonyiro and Garbatulla towns. IIED Country Report, IIED, London.

Jagwe, J.N. 2011. Impact of transaction costs on the participation of smallholder farmers and intermediaries in the banana markets of Burundi, Democratic Republic of Congo and Rwanda. Thesis Dissertation. Department of Agricultural Economics, Extenstion and Rural Development, University of Pretoria, South Africa.

Jalang'o, D., Otieno, D., and Oluoch-Kosura, W. 2018. Commercialization of African indigenous vegetables in Kenya. Chapter 8. (pp 36-45). In Adamseged and Bokelmann (eds.) Value chain development for food security in the context of climate change: Perspectives and lessons from a North-South capacity building project. Verlag Dr. Köster, Berlin.

Jolliffe, D., and Prydz, E.B. 2016. Estimating international poverty lines from comparable national thresholds. The Journal of Economic Inequality 14 (2): 185-198.

Kabeto, A. 2014. An analysis of factors influencing participation of smallholder farmers in red bean marketing in Halaba Special District, Ethiopia. Thesis Dissertation. Department of Agricultural Economics, University of Nairobi, Kenya.

Kaufmann, B., Nelson, W., Gudere, R., Canger, V., Golicha, D., Frank, M., Roba, H., Mwai, O. and Hülsebusch, C. 2012. Identifying local innovations in pastoral areas in Marsabit County, Kenya. German Institute for Tropical and Subtropical Agriculture (DITSL), Germany. Retrieved from: https://www.ditsl. org/images/articles/publications/manual.pdf. Accessed 3 Dec 2018.

Kenya Institute for Public Policy Research and Analysis (KIPPRA). 2018. Proceedings of the regional conference on building resilience to mitigate the impact of droughts and floods held from $5^{\text {th }}-7^{\text {th }}$ June in Nairobi, Kenya.Retrieved from: http://kippra.or.ke/wp-content/uploads/2017/05/ Proceedings-for-KIPPRA-Annual-Regional-Conference-2018-for-upload.pdf. Accessed 15 Apr 2019.

Kenya National Bureau of Statistics (KNBS). 2009. Kenya economic survey report. Nairobi: Government printers.

Kenya National Bureau of Statistics (KNBS). 2019. Kenya population and housing census: Volume I. Retrieved from: https:/www.knbs.or.ke/?wpdmpro=2019kenya-population-and-housing-census-volume-i-population-by-county-andsub-county\&wpdmdl=5615\&ind=PZ88hyEV4wr5SAI7R5Q0u_414 pBOVQOHVTICQuSkxrD2DGuvX4M0ougXX1Z6loxa. Accessed 26 Feb 2020.

Koech, O. 2014. Comparative evaluation of six indigenous rangeland grasses for fodder production under varying soil moisture contents in Tana River County, South Eastern Kenya. PhD Thesis. Department of Land Resource Management and Agricultural Technology, University of Nairobi, Kenya.
Koech, O., R. Kinuthia, G. Karuku, S. Mureithi, and R. Wanjogu. 2016. Field curing methods and storage duration affect the quality of hay from six rangeland grass species in Kenya. Ecological Processe 5(1):3.

Komarek, A. 2010. The determinants of banana market commercialization in Western Uganda. African Journal of Agricultural Research 5 (9): 775-784.

Kutu, A., and G. Wamwere-Njoroge. 2017. Kenya accelerated value chain development (AVCD) program - Livestock component: County project year 1 brief, Isiolo County. Nairobi: International Livestock Research Institute (ILRI) Retrieved from: https://stormpdf.com/livestock-component-county-projectyear-1-brief-avcd-program.html. Accessed 14 Jan 2018.

Lugusa, K. 2015. Fodder production as an adaptation strategy in the drylands: A case study of producer groups in Baringo County, Kenya. Thesis Dissertation. Department of Land Resource Management and Agricultural Technology, University of Nairobi, Kenya.

Lugusa, K., O. Wasonga, Y. Elhadi, and T. Crane. 2016. Value chain analysis of grass seeds in the drylands of Baringo County, Kenya: A producers' perspective. Pastoralism: Research, Policy and Practice 6 (1): 1-15.

Martey, E., M.R. Al-Hassan, and M.K. Kuwornu. 2012. Commercialization of smallholder agriculture in Ghana: A Tobit regression analysis. African Journal of Agricultural Research 7 (14): 2131-2141.

Mureithi, S. 2018. Commercial fodder production and its economic feasibility in ASAL counties. A policy brief by ILRI, AgrifoSe2030 and University of Nairobi. Retrieved from: https://www.slu.se/globalassets/ew/org/andra-enh/uadm/ global/agrifose/outputs/briefs/ilri/dr.-stephen-m.-mureithi-brief-october-2018. pdf. Accessed 3 Nov 2018.

Mureithi, S., A. Verdoodt, J. Njoka, C. Gachene, and E. Van Ranst. 2015. Benefits derived from rehabilitating a degraded semi-arid rangeland in communal enclosures, Kenya. Land Degradation and Development 27 (8): 1781-1872.

Muricho, D., Otieno, D., and Oluoch-Kosura, W. 2017. The role of pastoralists' innovations in managing land constraints and climate shocks in West Pokot, Kenya. A research paper presented at the agriculture for development conference (Agri4D), Uppsala, Sweden, $20-21^{\text {st }}$ September.

Muricho, D., D. Otieno, W. Oluoch-Kosura, and M. Jistrom. 2019. Building pastoralists' resilience to shocks for sustainable disaster risk mitigation: Lessons from West Pokot County, Kenya. International Journal of Disaster Risk Reduction 34: 429-435.

Muricho, G., Kassie, M., and Obare, G. 2015. Determinants of market participation regimes among smallholder maize producers in Kenya. International Maize and Wheat Research Centre Discussion Paper, Number 12.

Mwaura, J., J. Koske, and B. Kiprotich. 2015. Assessing economic viability of pasture enterprise as adaptation strategy in dry land ecosystems-a case of ljara, Kenya. Journal of Economics and Sustainable Development 6 (22): 29-45.

National Drought Management Authority (NDMA). 2018. Drought early warning bulletin for Isiolo County for December 2018. Retrieved from: http://ndma.go ke/index.php/resource-center/send/15-isiolo/5017-isiolo-december-2018. Accessed 13 Dec 2019.

Ngigi, M., Mueller, U., and Birner, R. 2015. The role of livestock portfolios and group-based approaches for building resilience in the face of accelerating climate change: An asset-based panel data analysis from rural Kenya. ZEFDiscussion Papers on Development Policy No. 205, Center for Development Research, Bonn, Germany.

Nyangaga, J., Gebremedhin, B., Baker, D., Lukuyu, B., and Randolph, T. 2009. Market survey of fodder supporting peri-urban livestock in Mandera. Report prepared for the Enhanced Livelihoods in the Mandera Triangle and Enhanced Livelihoods in Southern Ethiopia program.

Nyberg, G., P. Knutsson, M. Ostwald, I. Öborn, E. Wredle, D. Otieno, and A. Grönvall. 2015. Enclosures in West Pokot, Kenya: Transforming land, livestock and livelihoods in drylands. Pastoralism: Research, Policy and Practice 5 (1): 1-12.

Ochago, R., M. Mangheni, and R. Miiro. 2017. Which socio-economic factors matter in farmer group participation? Evidence from coffee pest management learning groups in Mt. Elgon Region, Uganda. International Journal of Agricultural Extension 5 (1): 23-38.

Oluoch-Kosura, W. 2010. Institutional innovations for smallholder farmers' competitiveness in Africa. African Journal of Agricultural and Resource Economics 5 (1): 227-242.

Omollo, E., Wasonga, V., Elhadi, Y., and Mnene, W. 2017. Grass seed value chain analysis in the Southern Kenya range lands of Makueni and Kajiado counties. A paper presented at the $5^{\text {th }}$ RUFORUM Biennial Conference and African Higher Education Week, Cape Town, South Africa, 15-21 October. 
Omollo, E., V. Wasonga, Y. Elhadi, and W. Mnene. 2018. Determinants of pastoral and agro-pastoral households' participation in fodder production in Makueni and Kajiado Counties, Kenya. Pastoralism: Research, Policy and Practice 8 (1): 1-10.

Opiyo, F., V. Wasonga, and M. Nyangito. 2014. Measuring household vulnerability to climate induced stresses in pastoral rangelands of Kenya: Implications for resilience programming. Pastoralism: Research, Policy and Practice 4 (1): 1-15.

Otieno, D. 2011. Economic analysis of beef cattle farmers' technical efficiency and willingness to comply with Disease Free Zones in Kenya. PhD. thesis. Newcastle University, United Kingdom.

Pain, A., and Levine, S. 2012. A conceptual analysis of livelihoods and resilience: Addressing the insecurity of agency'. Working Paper, Humanitarian Policy Group (HPG), Overseas Development Institute (ODI), London.

Peishi, Z. 2018. How cash and food transfers and asset creation can contribute to women's empowerment: Learning from Niger, Kenya and Zimbabwe World Food Programmes' collected papers on Gender and Cash Transfer Programmes in Humanitarian Contexts. Accessed 22 Jan 2019.

Place, F., and Kariuki, G. 2005. Initiatives for rural development through collective action: The case of household participation in group activities in the highlands of Central Kenya. CGIAR system wide program on collective action and property rights. Retrieved from: https://core.ac.uk/download/pdf/624272 8.pdf. Accessed 20 Feb 2018.

Randela, R., G. Alemu, and A. Groenewald. 2008. Factors enhancing market participation by small-scale cotton farmers. Agrekon 47 (4): 451-469.

Republic of Kenya. 2012. Kenya vision 2030 development strategy for northern Kenya and other arid lands Ministry of State, for development of northern Kenya and other arid lands. Nairobi: Government printers.

Republic of Kenya. 2013. Isiolo County integrated development plan. 2013-2017. Nairobi: Government printers.

Republic of Kenya. 2015. Isiolo County livestock strategy and plan of action. Nairobi: Government printers.

Shibia, A. 2018. Building household coping mechanisms with the effects of droughts and floods using financial instruments. Kenya Institute for Public Policy Research and Analysis (KIPPRA) policy brief number 12-2017-2018.

Thomas, M., Wasonga, O., and Ragwa, P. 2016. Technical evaluation of drought mitigation technologies implemented under food/cash for assets project in Isiolo County. An evaluation report submitted to Food and Agriculture Organization of the United Nations/World Food Programme.

United Nations (UN). 2017. Kenya flash appeal for September 2017 to December 2017. A report produced by the United Nations Office for the Coordination of Humanitarian Affairs on behalf of humanitarian partners in support of the national government, Nairobi, Kenya.

United States Agency for International Development (USAID). 2015. The Resilience and Economic Growth in the Arid Lands-Accelerated Growth (REGAL-AG) monthly report published by ACDINOCA.

Vance, C., and Buchheim, S. 2005. On the application of Heckman's sample selection model to travel survey data: Some practical guidelines. Proceedings of European transport and contributors' research to inform decision-making in transport-applied methods in transport planning-panel study, Strasbourg, France 18-20 September.

Wairore, J., S. Mureithi, V. Wasonga, and G. Nyberg. 2015. Enclosing the commons: Reasons for the adoption and adaptation of enclosures in the arid and semi-arid rangelands of Chepareria, Kenya. Springer Plus 4 (1): 1-11.

Wanyoike, F., Njiru, N. Kutu, A., Chuchu, S., Wamwere-Njoroge, G. and Mtimet, N. 2018. Analysis of livestock and fodder value chains in arid and semi-arid lands in Kenya. Nairobi, Kenya: International Livestock Research Institute (ILRI). Retrieved from: https://cgspace.cgiar.org/bitstream/handle/10568/91179/ avcd_livestock.pdf?sequence=6\&isAllowed=y . Accessed 27 Apr 2018.

Wasonga, V. 2009. Linkages between land-use, land degradation and poverty in semi-arid rangelands of Kenya: The case of Baringo district. Doctoral dissertation. Department of Range Management, University of Nairobi, Kenya.

Wasonga, V., Musembi, J., Rotich, K., Jarso, I., King-Okumu, C. 2016. Vegetation resources and their economic importance in Isiolo County, Kenya. International Institute for Environment and Development (IIED), London. http://pubs.iied.org/10141IIED . ISBN: 978-1-78431-247-3.

Wooldridge, J. 2002. Econometric analysis of cross section and panel data. Cambridge: MIT Press.

World Food Program (WFP). 2013. Building resilience through asset creation in Niger. Retrieved from: https://documents.wfp.org/stellent/groups/public/ documents/communications/wfp261744.pdf. Accessed 14 Jan 2018.
World Food Program (WFP). 2016. Asset creation project fact sheet. Retrieved from: https://www.wfp.org/content/wfp-kenya-factsheet-asset-creation. Accessed 14 Jan 2018.

World Initiative for Sustainable Pastoralism (WISP). 2010. Building climate change resilience for African livestock in sub-Saharan Africa - A program of the International Union for Conservation of Nature, Eastern and Southern Africa Regional Office. IUCN and WISP. ISBN 978283171260.

\section{Publisher's Note}

Springer Nature remains neutral with regard to jurisdictional claims in published maps and institutional affiliations.

\section{Submit your manuscript to a SpringerOpen ${ }^{\circ}$ journal and benefit from:}

- Convenient online submission

- Rigorous peer review

- Open access: articles freely available online

- High visibility within the field

- Retaining the copyright to your article

Submit your next manuscript at $\boldsymbol{\nabla}$ springeropen.com 